Fathi Elharare Ali Elhaniash ${ }^{1}$

Svetlana Stevović

University Union - Nikola Tesla,

Faculty of Construction Management, Belgrade, Serbia
SCIENTIFIC REVIEW ARTICLE doi:10.5937/ekonomika1604129E Received: November 08, 2016 Accepted: November 29, 2016

\title{
MEASUREMENT THE EFFICIENCY OF BUILDING PROJECT MANAGEMENT
}

\begin{abstract}
Construction industry has complexity in its nature because it contains large number of parties as clients, contractors, consultants, stakeholders, shareholders, regulators and others. Construction projects in Libya suffer from many problems and complex issues in performance such as cost, time and safety. The aim of this work is to identify and evaluate the main factors affecting the performance of construction projects in Libya.

Literature review about performance was reviewed to identify the factors affecting the Performance of construction projects. In addition, other local factors have been added as recommended by local experts. Pilot study of the questionnaire was achieved by a scouting sample, which consisted of 30 questionnaires. A questionnaire survey was conducted and 63 factors were identified, categorized into 10 groups, evaluated and ranked from owners, consultants and constructors perspectives. 120 questionnaires were distributed as follows: 25 to owners, 35 to consultants and 60 to contractors. 88 questionnaires were received (73\%) as follows: 17 (70\%) from owners, 25 (72\%) from consultants and 46 (77\%) from contractors as respondents. The most important factors agreed by the owners, consultants and contractors were: average delay because of closures and materials shortage; availability of resources as planned through project duration; leadership skills for project manager; escalation of material prices; availability of personals with high experience and qualification; and quality of equipments and raw materials in project.
\end{abstract}

Key words: Construction projects, performance of construction projects, performance indicators.

JEL Classification: L25

\section{МЕРЕЊЕ ЕФИКАСНОСТИ УПРАВЉАЫА ГРАЂЕВИНСКИМ ПРОЈЕКТИМА}

\footnotetext{
Апстракт

Грађевинска индустрија је по својој природи сложена, јер инкорпорира велики број учесника како клијената, извођача, консултаната, акционара,

${ }^{1}$ sanadfathi115@gmail.com

²svetlanas123@gmail.com
} 
регулаторних органа тако и других заинтересованих страна. Грађевински пројекти у Либији оптерећени су бројним и сложеним проблемима у извршену као што су трошкови, време и белбедност. Циљ овог рада је да идентификује и процени главне факторе који утичу на перформансе грађевинских пројеката у Либији.

Преглед литературе о перформансама разматран је у светлу препознавања фактора који утичу на перформансе грађевинских објеката. Поред тога, указано је на кључне локалне факторе што је идентификовано увидом од стране локалних стручњака. Пилот студија је реализована на узорку који се састојао од 30 питања. Истраживане је спроведено упитником којим су обухваћена 63 фактора, категорисаних у 10 група, оценених и рангираних из перспективе власника, консултаната и извођача. 120 упитника је дистрибуирано на следећи начин: 25 власницима, 35 консултанатима и 60 извођачима. Од испитаника је примљено 88 упитника односно 73\% и то: 17 (70\%) од стрне власника, 25 (72\%) од консултаната и 46 (77\%) од извођача. И власници и консултанти и извођачи сагласни су да су најважнији следећи фактори: просечна кашњења због несташице материјала, доступност ресурса на начин који је планом предвиђен уз поштовање рокова, лидерске способности пројектних менацера, скок цена материјала, доступност високо квалификоване радне снаге са озбиљним радним искуством, као и квалитет опреме и сировина потребних за реализацију пројекта.

Кључне речи: грађевински пројекти, извршавање грађевинских пројеката, индикатори учинка.

\section{Introduction}

Construction industry plays a major role in development and achievement the goals of society. Construction is one of the largest industries and contributes to about $10 \%$ of the gross national product (GNP) in industrialized countries (Navon, 2005, p. 476).

Construction industry has complexity in its nature because it contains large number of parties as clients, contractors, consultants, stakeholders, shareholders and regulators.

The performance of the construction industry is affected by national economies (Navon, 2005, p. 476).

In Libya, efficient construction projects can provide a solid platform for reviving the Libyan economy and for building a more balance and independent economy during stable political conditions.

Performance is related to many topics and factors such as time, cost, quality, client satisfaction; productivity and safety. Construction industry in Libya suffers from many problems and complex issues in performance. For example, construction of 15 dwelling units at Alzawijah Area suffered from poor performance because of delay for about 130 days. There are many realistic reasons such as closures, amendment of drawings and amendment of the design. In addition, there are other different reasons affecting construction projects performance in Libya such as poor management and leadership; 
inappropriate participants; poor relations and coordination; absence of motivation, control, monitor or decision making systems; inadequate infrastructure, political problems; cultural problems and economic conditions (UNRWA, 2000).

In this study, factors affecting the performance of construction projects in Libya will be analyzed. Performance indicators are used to measure performance in construction projects. These indicators can then be used for benchmarking purposes, and will be a key component of any organization's move towards achieving best practice in order to overcome performance problem. However, this study aims at identify the factors and attributes affecting the performance of construction projects in Libya.

\section{Problem of Performance in Construction Industry}

The failure of any construction project is mainly related to the problems and failure in performance. Moreover, there are many reasons and factors which attribute to such problem. (Ogunlana et al, 1996, p. 37-45) stated that the construction industry performance problems in developing economies can be classified in three layers: problems of shortages or inadequacies in industry infrastructure (mainly supply of resources), problems caused by clients and consultants and problems caused by contractor incompetence/inadequacies. (Okuwoga, 1998, p. 389) identified that the performance problem is related to poor budgetary and time control. (Long et al, 2014, p. 553) remarked that performance problems arise in large construction projects due to many reasons such as: incompetent designers/contractors, poor estimation and change management, social and technological issues, site related issues and improper techniques and tools. (Navon, 2005 , p. 467) stated that the main performance problem can be divided into two groups:

(a) Unrealistic target setting (i.e., planning) or

(b) Causes originating from the actual construction (in many cases the causes for deviation originate from both sources). Samson and Lem (2012) found that the traditional performance measurement systems have problems because of large and complex amount of information with absence of approaches to assist decision maker understand, organize and use such information to manage organizational performance. Navon (2005, p. 476) remarked that traditional project performance control is usually generic (e.g., cost control techniques). It relies on manual data collection, which means that it is done at low frequency (normally once a month) and quite some time after the controlled event occurred (i.e., not in real-time). Moreover, manual data collection normally gives low quality data.

Ling et al (2007) remarked that architectural, engineering and construction (AEC) firms may face difficulties managing construction projects performance in China because they are unfamiliar with this new operating environment. Kim et al (2008) stated that international construction projects performance is affected by more complex and dynamic factors than domestic projects; frequently being exposed to serious external uncertainties such as political, economical, social, and cultural risks, as well as internal risks from within the project. 


\section{Construction Management and Performance}

There is a strong relation between project management and project performance Management in construction industry is considered as one of the most important factors affecting performance of works. (Brown and Adams, 2000, p. 327-335) studied a new approach to the measurement of the effect of Building Project Management (BPM) on time, cost and quality outputs using 15 'cases' derived from UK data. The evaluation undertaken demonstrates that BPM as it is presently implemented in the UK fails to perform as expected in relation to the three predominant performance evaluation criteria; time, cost and quality.

Lehtonen (2001, p. 107-116) obtained a model for performance measurement which assist both firms' top management and operational managers for continuous feedback on operational activities. Thomas $(2002$, p. 339) stated that documenting and archiving performance data could be useful for future reference, such as for settling disputes on claims, and in maintenance and repair works. (Kuprenas, 2013, p. 25-32) remarked that quantification of the impacts of the project management processes are identified through three steps of analysis: comparison of summary statistics of design performance, proof of statistical significance of any differences and calculation of a least squares regression line of a plot of design performance measurement versus amount/ application of project management as a means to quantify management influence to design phase cost performance.

\section{Construction Projects and Performance}

Success of construction projects depends mainly on success of performance. Many previous researches had been studied performance of construction projects.

Dissanayaka and Kumaraswamy (1999, p. 31-42) remarked that one of the principle reasons for the construction industry's poor performance has been attributed to the inappropriateness of the chosen procurement system. Reichelt and Lyneis (1999, p.135-150) remarked three important structures underlying the dynamic of a project performance which are: the work accomplishment structure, feedback effects on productivity and work quality and effects from upstream phases to downstream phases. (Thomas, 2002, p. 339.349) identified the main performance criteria of construction projects as financial stability, progress of work, standard of quality, health and safety, resources, relationship with clients, relationship with consultants, management capabilities, claim and contractual disputes, relationship with subcontractors, reputation and amount of subcontracting.

Chan and Kumaraswamy (2012, p. 23) stated that construction time is increasingly important because it often serves as a crucial benchmarking for assessing the performance of a project and the efficiency of the project organization.

Cheung et al $(2014$, p. 361) identified project performance categories such as people, cost, time, quality, safety and health, environment, client satisfaction, and communication.

It is obtained by (Navon, 2005, p. 467) that a control system is an important element to identify factors affecting construction project effort. For each of the project 
goals, one or more Project Performance Indicators (PPI) is needed. Pheng and Chuan (2006, p. 24) obtained that human factors played an important role in determining the performance of a project. Ugwu and Haupt (2007, p. 665-680) remarked that both early contractor involvement (ECI) and early supplier involvement (ESI) would minimize constructability-related performance problems including costs associated with delays, claims, wastages and rework, etc. Ling et al (2007) obtained that the most important of practices relating to scope management are controlling the quality of the contract document, quality of response to perceived variations and extent of changes to the contract. It was recommended for foreign firms to adopt some of the project management practices highlighted to help them to achieve better project performance in China.

\section{Information Technology and Construction Projects Performance}

Information technology technique is very important in the entire world. Information technology (IT) opens new visions in the businesses and industries performance of the world. The construction industry is considered as one of the industries using IT technique such as software management systems, database and communications. For many years, many processes, functions, operations were done difficulty because of absence of IT field. In addition, most of the work was done manually which lead to more cost, time and poor performance. Furthermore, IT usage in the construction industry leads to many changes, innovations and developing in many aspects which lead finally to good and strong performance. There are many benefits and relations of using IT in the construction projects such as: greater use of IT correlates with better project performance, owners and contractors realize meaningful benefits, IT affects schedule compression beneficially, and overall project cost savings which lead to a success performance of project (Schwegler et al, 2001).

Nitithamyong et al $(2014$, p. 491) remarked that information Technology (IT) is now routinely used in the construction industry as a tool to reduce some of the problems generated by fragmentation. The use of IT improves coordination and collaboration between firms participating in a construction project, leading to better communication practices and so good performance. Its benefits include an increase in the quality of documents and the speed of the work, better financial control and communications, and simpler and faster access to common data as well as a decrease in documentation errors.

Thomas (2002, p. 339) proposed contractor Performance Appraisal and Reporting (PAR) system for reviewing contractor performance at an organizational level.

Advancements in World Wide Web techniques provide enhanced capacities to collect compile and disseminate performance-related information to various construction stakeholders in a timely and cost-effective manner. Becerik (2004) stated that the rapid advances of web-based project management and collaboration technology offer new opportunities to improve existing construction project performance. Cheung et al (2014, p. 361) obtained framework software to measure project performance based on project performance measurement system (PPMS). The system contains four stages which are data entry, database, reporting and action. This system has eight categories to measure performance which are people, cost, time, quality, safety and health, environment, client satisfaction, and communication. Goh (2005, p. 13) remarked that information technology 
management leads to performance improvement in the construction industries. For instance, in Singapore 2003, general administration, design, project management, site management were enhanced by using of IT. In addition, there were more advantages as quick working, good quality of work and fast access of information.

\section{Factors Affecting Performance of Managers}

Ogunlana et al, (1996, p. 45-50) recommended the need for focused effort by economy managers and construction industry associations to provide the infrastructure needed for efficient project management and performance. Dissanayaka and Kumaraswamy (1999, p. 42-45) stated that the knowledge that would influence potential performance enables project managers to pay special attention to control performance more effectively.

Chan and Kumaraswamy (2012, p. 35-40) remarked that effective communication and fast information transfer between managers and participants help to accelerate the building construction process and performance. Kuprenas (2013, p. 32-39) studied the impact of the use of a project management based organizational structure, project manager training, frequency of design meetings, and frequency of design reports on design phase cost performance. The process of a design team meeting frequency and the process of written reporting of design phase progress were found to be statistically significant in reducing design phase costs.

Navon (2005, p. 481) stated that data are collected and used for construction managers as a basis to evaluate the project performance indicators (PPI) actual value to compare it with the planned value and forecast its future value based on past performance. Pheng and Chuan (2006, p. 42) identified the importance of the working environment variables for the performance of a project manager in the private and public sectors according to three main groups which are job condition, project characteristic and organizational related categories. The result revealed that working hours, physical condition of project site, complexity of project, material and supplies, project size, duration of project and time availability were viewed differently in terms of importance by the contractors and consultants groups. Team relationship was ranked as the most important variable affecting the performance of a project manager. It is obtained that project manager's experiences do not have much effect on how they perceive their working environment.

\section{Factors Affecting Cost and Time Performance}

Chan and Kumaraswamy (2012. p. 35-40) remarked that studies in various countries appear to have contributed significantly to the body of knowledge relating to time performance in construction projects over the past three decades, while Iyer and Jha (2005, p. 283) remarked that project performance in term of cost is studied since 1960s. These studies range from theoretical work based on experience of researcher on one end to structured research work on the other end. Moreover, Pheng and Chuan (2006, p. 42) stated that there have been many past studies on project performance according to cost and time factors. 
Chan and Kumaraswamy (1996, p. 569- 578) stated that a number of unexpected problems and changes from original design arise during the construction phase, leading to problems in cost and time performance. It is found that poor site management, unforeseen ground conditions and low speed of decision making involving all project teams are the three most significant factors causing delays and problems of time performance in local building works. Okuwoga (1998, p. 395) stated that cost and time performance has been identified as general problems in the construction industry worldwide. Dissanayaka and Kumaraswamy (1999, p. 42-45) remarked that project complexity, client type, experience of team and communication are highly correlated with the time performance; whilst project complexity, client characteristics and contractor characteristics are highly correlated with the cost performance. (Reichelt and Lyneis, 1999, p. 135-150) obtained that project schedule and budget performance are controlled by the dynamic feedback process.

Those processes include the rework cycle, feedback loops creating changes in productivity and quality, and effects between work phases.

Chan (2001, p. 223-229) identified that the best predictor of average construction time performance of public sector projects in Malaysia is $\mathrm{T}=269 \mathrm{C} 0.32$. This relationship can serve as a convenient tool for both project managers and clients to predict the average time required for delivery of a construction project. (Kuprenas, 2013, p. 25-32) stated that process of a design team meeting frequency and the process of written reporting of design phase progress were found to be statistically significant in reducing design phase costs. Otherwise, the use of project manager training and a project management based organizational structure were found to be processes that do not create a statistically significant in reducing design phase costs.

Iyer and Jha (2005, p. 283.295) remarked that the factors affecting cost performance are: project manager's competence; top management support; project manager's coordinating and leadership skill; monitoring and feedback by the participants; decision making; coordination among project participants; owners' competence; social condition, economical condition and climatic condition. Coordination among project participants was as the most significant of all the factors having maximum influence on cost performance of projects. Love et al (2005, p. 187-194) examined project time-cost performance relationships by using project scope factors for 161 construction projects that were completed in various Australian States. It is noticed that gross floor area and the number of floors in a building are key determinants of time performance in projects.

Furthermore, the results indicate that cost is a poor predictor of time performance. Chan and Kumaraswamy (2012, p. 35-40) proposed specific technological and managerial strategies to increase speed of construction and so to upgrade the construction time performance. It is remarked that effective communication, fast information transfer between project participants, the better selection and training of managers, and detailed construction programs with advanced available software can help to accelerate the performance. Jouini et al (2004, p. 367) stated that managing speed in engineering, procurement and construction projects is a key factor in the competition between innovative firms. It is found that customers can consider time as a resource and, in that case, they will encourage the contractor to improve the time performance. 


\section{Measurement of Project Performance}

Karim and Marosszeky (1999) stated that performance measurement systems have been one of the primary tools used by the manufacturing sector for business process reengineering in order to monitor the outcomes and effectiveness of implementation.

Brown and Adams (2000, p. 327-335) obtained an evaluation framework to measure the efficiency of building project management (BPM) by using conventional economic analysis tools such as time, cost and quality. Lehtonen (2001, p. 107-116) stated that performance measurement systems are imminent in the construction firms. Samson and Lema (2002) stated that effective and efficient management of contractors' organizational performance requires commitment to effective performance measurement in order to evaluate, control, and improve performance today and in the future.

Tangen (2004, p. 726-737) obtained that performance measurement is a complex issue that normally incorporates at least three different disciplines: economics, management and accounting. Measurement of performance has garnered significant interest recently among both academics and practitioners. Tangen (2004, p. 726-737) remarked that the choice of a suitable measurement technique depends on a number of factors, including the purpose of the measurement; the level of detail required; the time available for the measurement; the existence of available predetermined data; and the cost of measurement.

Navon (2005, p. 481) defined performance measurement as a comparison between the desired and the actual performances. For example, when a deviation is detected, the construction management analyzes the reasons for it. The reasons for deviation can be schematically divided into two groups:

(a) Unrealistic target setting (i.e., planning) or

(b) Causes originating from the actual construction (in many cases the causes for deviation originate from both sources).

Cheung et al (2014) stated that New South Wales Public Works Department in Australia launched a Project Performance Evaluation (PPE) framework, which covers a wide range of performance parameters. PPE parameters are communication, time, cost, quality, safety, claims and issues resolution, environment, contract relations. The main purpose of PPE is to extend project performance measures to cover soft parameters also, such as communication and dispute resolution. In the UK, a project performance measurement tool referred to as the Key Performance Indicators (KPIs) was developed by the KPI working group under the UK Construction Industry Best Practice Program to include time, cost, quality, client satisfaction, change orders, business performance, health and safety. The three major steps in implementing KPIs are as follows: Decide what to measure, Collect data and calculate the KPIs.

However, both the PPE and KPIs are valuable tools for measuring project performance over a period of time. Anyway, it is obtained from previous study that both methods PPE and KPIs can be used for measuring of performance as the indicators are similar in two methods. In this study KPIs method will be used to measure performance.

Iyer and Jha $(2005$, p. 295) stated that measuring the performance of any construction project is a very complex process because modern construction projects are generally multidisciplinary in nature and they involve participation of designers, contractors, subcontractors, specialists, construction managers, and consultants. With the 
increasing size of the project, number of participants in the project also increases. The objectives or goals of all participants need not be same even in a given project. Hence to measure performance of a project without specifying the participant and without specifying the criteria for judging the performance holds no meaning. Past researchers have employed different criteria such as compliance to schedule, cost and quality to judge the project performance.

Lehtonen (2001, p. 107-116) proposed new framework for measuring construction logistics by using two-dimensions in order to improve productivity. The first dimension (use of measures) contains two kinds of measures. One of these kinds is called improvement measures which help construction industry to find out the problems with current practices. These measures are mainly used during development projects. Another kind is called monitoring measures which are used for continuous monitoring of operations. The second dimension of the framework is the focus of measures. It clarifies at which organizational level measures can be used. There should be information available at the company and project level, as well as at the specific supplier or subcontractor level.

Samson and Lema (2012) proposed performance measurement system. The system comprises of construction business perspective including innovation and learning, processes, project, stakeholders, and financial perspective. The indicators developed from perspectives are categorized into three main groups which are drivers' indicators, process indicators and results indicators. The key to the success or failure of the measurement system are leadership commitment; employees' involvement and empowerment; and information coordination and management. Shen et al (2005, p. 309) presented a method for measuring the environmental performance of construction activities committed by a contractor through calculating the contractor's environmental performance score (EPS). The level of EPS serves as a simple indicator for measuring and communicating the level of a contractor's environmental performance.

Cost performance can be measured through a cost performance index (CPI) computed as (Kuprenas, 2003):

$\mathrm{CPI}=\mathrm{BCWP} / \mathrm{ACWP}$

Where:

- $\quad \mathrm{BCWP}=$ budgeted cost of the work performed

- $\quad \mathrm{CWP}=$ actual cost of the work performed.

From previous equation:

- If CPI value of one means, the cost was as planned (at the budget Value)

- If CPI value above one means, the project was below its budget

- If CPI of less than one means, the project exceeded its budget.

Based on previous equation, time performance is measured through a schedule performance index (SPI) computed as:

$\mathrm{SPI}=\mathrm{BCWP} / \mathrm{BCWS}$

Where:

- $\mathrm{BCWP}=$ budgeted cost of the work performed

- BCWS = budgeted cost of the work scheduled.

From previous equation:

- If SPI value of one means, the time was as planned (at the time Value)

- If SPI value above one means, the project was ahead of schedule

- If SPI of less than one means, the project was behind schedule 


\section{Conclusion}

To determine owners, consultants and contractors perceptions towards the relative importance of the key performance indicators in Libyan construction projects

A structured questionnaire survey approach was considered to study the impact of various attributes and factors affecting construction projects performance. The questionnaire assists to study the attitude of owners, consultants and contractors towards key performance indicators in the construction industry.

The respondents are classified as projects managers, site engineers/office engineers and organizations managers, as they have a practical experience in construction industries field. Their sufficient experiences were a suitable indication to find out the perceptive of the relative importance of project performance indicators of the owner, consultant and contractor parties. Their experiences included many construction fields such as buildings, roads and transportations, and water and sewage projects.

The results were analyzed, discussed to obtain the most performance indicators. The relative importance index method (RII) was used here to determine owners, consultants and contractors perceptions of the relative importance of the key performance indicators in Libyan construction projects.

To identify the most significant key performance indicators of construction projects in Libya.

According to owners, consultants and contractors the average delay because of closures and materials shortage was the most important performance factor as it has the first rank among all factors with RII $=0.941$ for owners, 0.896 for consultants and 0.943 for contractors. Construction projects in Libya are suffering from complex problems because of closures and materials shortage. These problems can be considered as an obstacle for performance of projects.

Availability of resources as planned through project duration has been ranked by the owners respondents in the third position with RII equal 0.871 , has been ranked by the consultant's respondents in the second position with RII equal 0.858 and has been ranked by the contractor's respondents in the third position with RII equal 0.904 . This factor can be considered as an important for three parties and has a similar rank for all parties as it affects directly on project performance such as time. If resources are not available as planned through project duration, the project will suffer from problem of time and cost performance.

The most important factors agreed by the owners, consultants and contractors as the main factors affecting the performance of construction projects in Libya were: escalation of material prices; availability of resources as planned through project duration; average delay because of closures and materials shortage; availability of personals with high experience and qualification; quality of equipments and raw materials in project; and leadership skills for project manager. However, there are some factors which can be considered as more important for one party than for others. This is because contractors are interested with operational and managerial factors. However, the owners and consultants considered the client and technical factors to be more important than operational ones. 


\section{References}

Brown Andrew and Adams John, (2000), Measuring the effect of project management on construction outputs: a new approach, International Journal of Project Management, Vol. 18.

Chan Albert P.C., (2001), Time. cost relationship of public sector projects in Malaysia, International Journal of Project Management, Vol.19.

Chan Daniel W. M. and Kumaraswamy Mohan M.,(1996), An evaluation of construction time performance in the building industry, Building and Environment, Vol. 31, No. 6.

Chan Daniel W.M. and Kumaraswamy Mohan M., (2012), Compressing construction durations: lessons learned from Hong Kong building projects, International Journal of Project Management, Vol.20.

Cheung Sai On, Suen Henry C.H. and Cheung Kevin K.W., (2014), PPMS: $a$ Webbased construction Project Performance Monitoring System, Automation in Construction, Vol. 13.

Dissanayaka Sunnil M. and Kumaraswamy Mohan M., (1999), Comparing contributors to time and cost performance in building projects, Building and Environment, Vol. 34.

Goh Bee Hua, (2005), IT barometer 2003: survey of the Singapora construction industry and a comparison of results, ITcon Vol. 10.

Iyer K.C. and Jha K.N., (2005), Factors affecting cost performance: evidence from Indian construction projects, International Journal of Project Management, Vol. 23.

Jouini Sihem Ben Mahmoud, Midler Christophe and Garel Gilles, (2004), Timetomarket vs. time-to-delivery; managing speed in engineering, Procurement and Construction projects, International Journal of Project Management, Vol.22.

Karim K. and Marosszeky M., (1999), Process monitoring for process re-engineering using key performance indicators, International conference on construction process reengineering, CPR 99, Sedney UNSW 12-13 July, Building Research center.

Kim Du Y., Han Seung H, Kim Hyoungkwan and Park Heedae, (2008), Structuring the prediction model of project performance for international construction projects: A comparative analysis, Expert Systems with Applications.

Kuprenas John A., (2013), Project management actions to improve design phase cost performance, Journal of Management in Engineering, Vol. 19, and No.1.

Lam K.C., Wang D., Lee Patricia T.K., Tsang Y.T., (2012), Modeling risk allocation decision in construction contracts, International Journal of Project Management.

Lehtonen Tutu Wegelius, (2001), Performance measurement in construction logistics, International Journal of Production Economics, Vol. 69.

Ling Florence Yean Yng, Low Sui Pheng, Wang Shou Qing and Lim Hwee Hua, (2007), Key project management practices affecting Singaporean firms.project performance in China, International Journal of Project Management 
Long Nguyen Duy, Ogunlana Stephen, Quang Truong and Lam Ka Chi, (2004), Large construction projects in developing countries: A case study from Vietnam, International Journal of Project Management, and Vol. 22.

Love Peter E. D., Tse Raymond Y. C. and Edwards David J., (2005), Time-Cost Relationships in Australian Building Construction Projects, Journal of Construction Engineering and Management, Vol. 131, No. 2.

Navon Ronie, (2005), Automated project performance control of construction projects, Automation in Construction, Vol. 14.

Nitithamyong Pollaphat and Skibniewski Miroslaw J., (2014), Web-based construction project management systems: how to make them successful? Automation in Construction, Vol. 13.

Ogunlana Stephen O, Promkuntong Krit and Jearkjirm Vithool, (1996), Construction delays in a fast-growing economy: comparing Thailand with other economies, International Journal of Project Management, Vol. 14.

Okuwoga Adeyinka A., (1998), Cost Time performance of public sector housing projects in Nigeria, Habital Intl., Vol. 22, No. 4.

Pheng Low Sui and Chuan Quek Tai, (2006), Environmental factors and work performance of project managers in the construction industry, International Journal of Project Management, Vol. 24.

Reichelt Kimberly and Lyneis James, (1999), The dynamic of project performance: Benchmarking the drivers of cost and schedule overrun, European management journal, Vol. 17, No.2.

Samson M and Lema NM, (2012), Development of construction contractors performance measurement framework, 1st International Conference of Creating a Sustainable

Schwegler Benedict R., Fischer Martin A., O.Connell Michael J., Hänninen Reijo and Laitinen Jarmo, (2001), near- medium- and long-term benefits of information technology in construction, Center of integrated facility engineering.

Shen Li-Yin, Lu Wei-Sheng, Yao Hong and Wu De-Hua, (2005), A computer-based scoring method for measuring the environmental performance of construction activities, Automation in Construction, Vol.14.

Tangen Stefan, (2004), Professional practice performance measurement: from philosophy to practice, International Journal of Productivity and Performance Management, Vol. 53, No. 8.

Thomas S. Ng, Palaneeswaran Ekambaram and Kumaraswamy Mohan M., (2002), A dynamic e-Reporting system for contractors performance appraisal, Advances in Engineering Software, Vol. 33.

Ugwu O.O. and Haupt T.C., (2007), Key performance indicators and assessment methods for infrastructure sustainability - a South African construction industry perspective, Building and Environment, Vol. 42. 